\title{
Technical Note: Preliminary estimation of rockfall runout zones
}

\author{
M. Jaboyedoff ${ }^{1,2}$ and V. Labiouse ${ }^{1}$ \\ ${ }^{1}$ LMR - ENAC - Ecole Polytechnique Fédérale de Lausanne - EPFL, 1015 Lausanne, Switzerland \\ ${ }^{2}$ Institute of Geomatics and Analysis of Risk, Amphipôle - 338, Faculté des géosciences et de l'environnement, \\ University of Lausanne, 1015 Lausanne, Switzerland
}

Received: 22 August 2010 - Revised: 6 December 2010 - Accepted: 24 January 2011 - Published: 15 March 2011

\begin{abstract}
Rockfall propagation areas can be determined using a simple geometric rule known as shadow angle or energy line method based on a simple Coulomb frictional model implemented in the CONEFALL computer program. Runout zones are estimated from a digital terrain model (DTM) and a grid file containing the cells representing rockfall potential source areas. The cells of the DTM that are lowest in altitude and located within a cone centered on a rockfall source cell belong to the potential propagation area associated with that grid cell. In addition, the CONEFALL method allows estimation of mean and maximum velocities and energies of blocks in the rockfall propagation areas. Previous studies indicate that the slope angle cone ranges from $27^{\circ}$ to $37^{\circ}$ depending on the assumptions made, i.e. slope morphology, probability of reaching a point, maximum run-out, field observations. Different solutions based on previous work and an example of an actual rockfall event are presented here.
\end{abstract}

\section{Introduction}

Rockfall hazard is a delicate task to assess because it is very difficult to predict the exact trajectory of any block of rock. The uncertainties propagation is comparable to that occurring in the trajectory prediction of a billiard ball after several collisions (Ruelle, 1987). Rockfall hazard mapping requires definition of the run-out distance and the area which can be reached by blocks, i.e. the propagation area. The CONEFALL method described in this paper is based on a simple frictional model assuming that the rockfall propagation areas can be modelled by analogy with a block sliding along a slope (Heim, 1932). Its aim is to obtain a fast estimation of

Correspondence to: M. Jaboyedoff (michel.jaboyedoff@unil.ch) the potential of rockfall prone areas at a regional scale based on the "shadow angle" approach or, in other words, the line of energy angle method (Onofri and Candian, 1979; Toppe, 1987; Wieczoreck et al., 1999; Lied, 1977; Evans and Hungr, 1993; Corominas, 1996; Jaboyedoff and Labiouse, 2003). CONEFALL has already been used by other authors to assess rockfall hazard (Aksoy and Ercanoglu, 2006; Ghazipour et al., 2008). In this paper, it is assumed that the source areas are known. They can be defined by different methods (Aksoy and Ercanoglu, 2006; Jaboyedoff and Labiouse, 2003; Loye et al., 2009). The software can be found as supplemental material on NHESS website or on the web site: http://www.quanterra.org/softs.htm; the code is available on request.

Predicting the rockfall runout distance and propagation areas, i.e. the areas potentially under the threat of rockfall, is still a challenge. Various solutions exist, ranging from the observed location of existing fallen blocks to 3-D kinematics modelling (Descoeudres and Zimmermann, 1987; Spang, 1987; Stevens, 1996; Guzzetti et al., 2002; Lan et al., 2007). Run-out distance estimations need calibrations based on direct observations, for which the reliability depends on the quantity and frequency of rockfall. This is also true for source areas. As a consequence, the more transparently the observations can be made, the better the calibration is.

During the last twenty-five years, kinematical rockfall computer modelling has been increasingly developed (Piteau and Clayton, 1978; Azimi et al., 1982; Descoeudres and Zimmermann, 1987; Hoek, 2007; Labiouse et al., 2001; Guzzetti et al., 2002 and references therein; Crosta and Agliardi, 2004). Furthermore, the widespread availability of digital terrain models (DTM) has strengthened this trend and permits 3-D modelling (Guzzetti et al., 2002; Crosta and Agliardi, 2004; Dorren et al., 2006), because this is the basic data needed for rockfall modelling.

Published by Copernicus Publications on behalf of the European Geosciences Union. 
Historically, simple models were first developed for very large rockfalls, i.e. rock avalanches. Heim (1932) pointed out that for such deposits the angle (Fahrböschung $\gamma$ ) between the line joining the top of the source cliff and the tip of the deposit follows a power law of the landslide volume (Scheidegger, 1973). Heim made the analogy with a mass moving along the topography dissipating energy by friction. The friction can be linked to an apparent friction angle equivalent to $\gamma$.

This principle was modified and applied to rockfalls without volume dependency using a predefined angle of the line joining the source to the stop point of blocs $\left(\phi_{\mathrm{p}}\right) . \phi_{\mathrm{p}}$ ranges from $22^{\circ}$ to $37^{\circ}$ depending on assumptions (Fig. 1a) and based on field evidence (Wieczoreck et al., 1999; Evans and Hungr, 1993; Toppe, 1987; Onofri and Candian, 1979). Such a model can be quickly applied to large areas, where a preliminary investigation of the potential rockfall propagation areas is needed starting from known source areas, or for very large rockfalls based on the Heim theory, which is based on the estimation of friction angle depending on volumes.

CONEFALL permits application of this shadow angle principle with grid files DTM that can be used in a geographical information system (GIS). This method can be applied to prioritize detailed investigation based on a global risk analysis by crossing objects at risk and potential rockfall areas.

\section{Previous work on rockfall trajectory modelling}

The principles of rockfall trajectory modelling were stated by Ritchie (1963), who completed experimental studies of rockfall trajectories, and came up with a classification scheme for rockfall. Rockfall trajectories can be calculated using classical kinematics equations (Piteau and Clayton, 1978; Azimi et al., 1982; Descoeudres and Zimmermann, 1987; Guzzetti et al., 2002). The loss of energy at the impact points is commonly modelled using coefficients of restitution, which depend on a number of factors, including mass, shape, and velocity of the boulder. Coefficients of restitution are usually expressed as the ratio of the velocity (or ratio of energy) before and after the impact, eventually for normal and tangential velocity components. Sliding and rolling can be added to the simulation. The blocks are simulated either by points (lumped mass) or rigid bodies. It means that either the trajectories depend on the block shapes, or the mass is concentrated in a point and the influence of shape is given by additional random parameters (Stevens, 1996). For most of the parameters used for the impact calculation, a stochastic part can be added to obtain more realistic results and to reflect the fact that parameters are varying along a slope (Scioldo, 2001; Dudt and Heidenreich, 2001; Guzzetti et al., 2002; Crosta and Agliardi, 2004; Dorren et al., 2006).

It must be noted that observations and modelling in 3 dimensions indicate that the trajectories can be spread around the steepest slopes in a range of $\pm 20^{\circ}$ (Agliardi and Crosta, 2003). Modelling has shown that the spreading in-

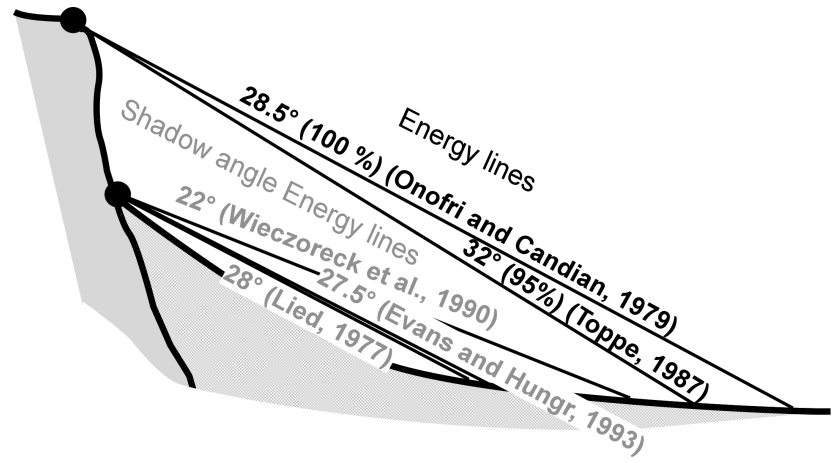

Fig. 1a. Energy line used for the cone method from the top or the bottom of a cliff (shadow angle), according to various authors (modified after Crosta et al., 2001).

creases with a smaller DTM grid size, i.e. more accurate (Agliardi and Crosta, 2003). But this can also be achieved by increasing the variability of a DTM altitude of coarser mesh introducing statistical distribution for the altitude variability (Crosta and Agliardi, 2003; Jaboyedoff et al., 2006).

Using GIS, Van Dijke and Van Westen (1990) and Heinimann et al. (1998) as well as Dorren and Seijmonsbergern (2003) simulated rockfall paths starting from source cells and moving to the next one by choosing the nearest neighbouring cell with the lowest elevation. The maximal run-out distance and velocity are computed using an analogy to a sliding coefficient (Scheidegger, 1973). In that case, if a digitized map containing data on the superficial geology exists, sliding coefficients can be changed depending on the geological type. Then potential rockfall propagation areas are simulated assuming that the falling rocks follow water flow paths limiting the runout distance by using the energy line, too. This leads to results similar to kinematics modelling (Utelli, 1999). The disadvantage of these methods is that small topographic or morphological irregularities may affect the rockfall trajectory substantially. Menéndez Duarte and Marquinez (2002) used GIS to determine watershed below rockfall sources identified as propagation zones (rockfall basin).

Using the energy line angle $\left(\phi_{\mathrm{p}}\right)$, Onofri and Candian (1979) observed that $50 \%$ of blocks are stopped for $\phi_{\mathrm{p}}>33.5^{\circ}, 72 \%$ for $\phi_{\mathrm{p}}>32^{\circ}$, and $100 \%$ for $\phi_{\mathrm{p}}>28.5^{\circ}$. Toppe (1987) developed a similar approach for maximum runout distances of snow avalanche and rockfall hazard mapping using a $\phi_{\mathrm{p}}$ deduced from the parameters extracted from the fitting of the slope profile by a parabola. Toppe (1987) indicates that $50 \%$ of the rockfall boulders are stopped before $45^{\circ}$ and $95 \%$ for $\phi_{\mathrm{p}}>32^{\circ}$. Gerber (1994) gave three substratum-dependent limits resulting in $100 \%$ of blocks being stopped: $33^{\circ}, 35^{\circ}$ and $37^{\circ}$. 
The energy line angle $\phi_{\mathrm{p}}$ can also be calculated from the bottom of the cliff or the top of the talus slope, instead of the rockfall source area (Lied, 1977; Hungr and Evans, 1988; Evans and Hungr, 1993) (Fig. 1a). In that case, it is called the shadow angle principle. This assumption can be used when the slope profile contains a slope break creating bolder rebounds where most of the kinetic energy is lost and then it represents a new start of the fall and bounce along the slope (Evans and Hungr, 1993). Lied (1977) found that all the blocks are stopped at an angle $\phi_{\mathrm{p}}$ of $28^{\circ}-30^{\circ}$. The term "shadow angle" is preferably used when the limit is set from the bottom of the cliff, even if the concept of energy line can still be applied because it is assumed that most of the kinetic energy is lost after the first rebound (Jaboyedoff and Labiouse, 2003). Evans and Hungr (1993), using numerous case-studies, set a shadow angle $\left(\phi_{\mathrm{p}}\right)$ at $27.5^{\circ}$. These limits are obviously "average" maximum runout points. Statistically, a small percentage of blocks can go beyond the $\phi_{\mathrm{p}}$, depending on the slope land cover type. Evans and Hungr (1993) indicate that $\phi_{\mathrm{p}}$ can be as low as $24^{\circ}$, whereas Wieczorek et al. (1999) found a different lower value at $22^{\circ}$ for the Yosemite valley, in Central California.

\section{Theoretical background of CONEFALL}

CONEFALL basically uses the principle of Heim (1932), modified and applied to rockfall. Following Heim (1932), the run-out distance $(L)$ of a rock avalanche can be estimated using the intersection of a line connecting the top of the rockfall scar with a slope equal to $\tan \gamma=\Delta z / L$ with the topography, $\Delta z$ being the difference in elevation between the top and the bottom. In the rockfall version the source cliff is replaced by the location of the rockfall source and the angle $\gamma$ is replaced by a fixed limited value $\phi_{\mathrm{p}}$ (Onofri and Candian, 1979). The energy loss along a complex rockfall trajectory depends on several different mechanisms, but the average of the rockfall energy dissipation can be modelled by friction instead of a punctual loss of energy at impact points, sliding and rolling. This concept can be used because statistically, the energy loss along a slope can be assumed linear on average, which leads in fact to a normal distribution of the block stop point distances around a mean value (Jaboyedoff and Pedrazzini, 2010). This justifies the concept by assuming threshold limits for propagation. The energy balance of a rockfall boulder starting from an elevation $H$ is given by (Heim, 1932; Scheidegger, 1973; Evans and Hungr, 1993):

$m g H-m g h(x)=\frac{1}{2} m v(x)^{2}+m g x \mu$

where: $m$ is the mass of the block, $g$ is gravity acceleration, $x$ the horizontal coordinate, $h(x)$ the elevation of the topographic surface at point $(x, h(x)), v(x)$ the velocity at point $x$, and $\mu$ the mean kinetic coefficient of friction (Fig. 1b). Rotational energy is not considered for the sake of simplicity.

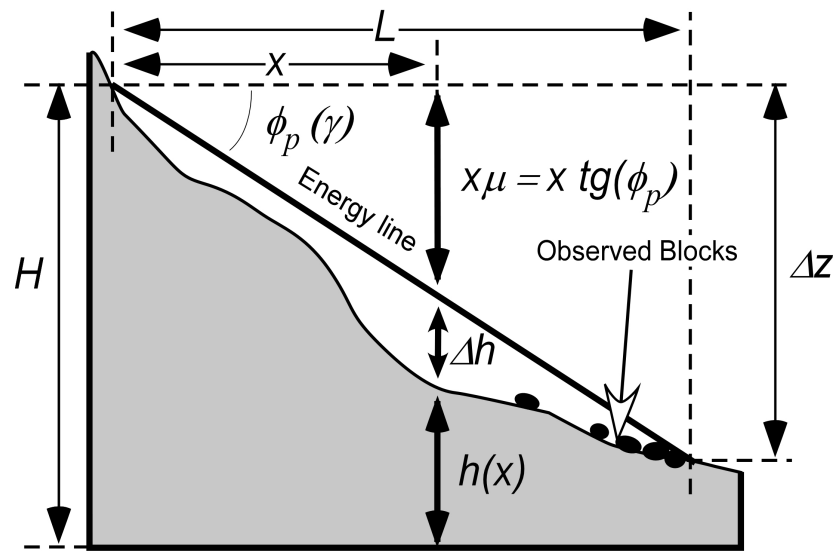

Fig. 1b. Variables used to calculate velocities and energies based on the energy line concept. The example uses the more distant block to define $\phi_{\mathrm{p}}$ and estimate $\Delta h$, which is used to calculate the velocity $v=\sqrt{2 g \Delta h}$. This illustrates the tailor-made possibilities of the cone method.

Rearranging terms to estimate the stopping point horizontal distance $x_{\text {stop }}$ by putting $v(x)=0$, and using $\mu=\operatorname{tg} \phi_{\mathrm{p}}$, we obtain:

$\mu=\operatorname{tg} \phi_{\mathrm{p}}=\frac{H-h\left(x_{\text {stop }}\right)}{x_{\text {stop }}}$

Hence, the boulder stops where the line from the rockfall source area with a slope equal to $\phi_{\mathrm{p}}$ intersects the topographic surface. This line is the energy line. Equation (2) provides a physical meaning to $\phi_{\mathrm{p}}$, as a mean kinematic coefficient of friction. From Eq. (1) we can estimate the boulder velocity for any $\mathrm{x}$-position:

$v(x)=\sqrt{2 g\left(H-h(x)-x \operatorname{tg} \phi_{p}\right)}$

From Eq. (3) it can be seen that if $v(x)$ is constant, the topographic slope $\alpha$ is equal to $\phi_{\mathrm{p}}$. Hence, where $\alpha>\phi_{\mathrm{p}}$ the boulder accelerates, and where $\alpha<\phi_{\mathrm{p}}$, the boulder decelerates. Assuming that $\Delta h$ is the difference of altitude between the energy line and topography, Eq. (3) can be rearranged to obtain:

$\Delta h=\frac{v^{2}(x)}{2 g}$

The cone method overestimates the lateral extension of the propagation zone because a cone posses a wider aperture than the observed spreading. As indicated previously in the case of a regular topography, the trajectories are spread out in a range of around $\pm 20^{\circ}$ on both sides of the greater slope. Depending on local morphology, this aspect must be taken into consideration. 


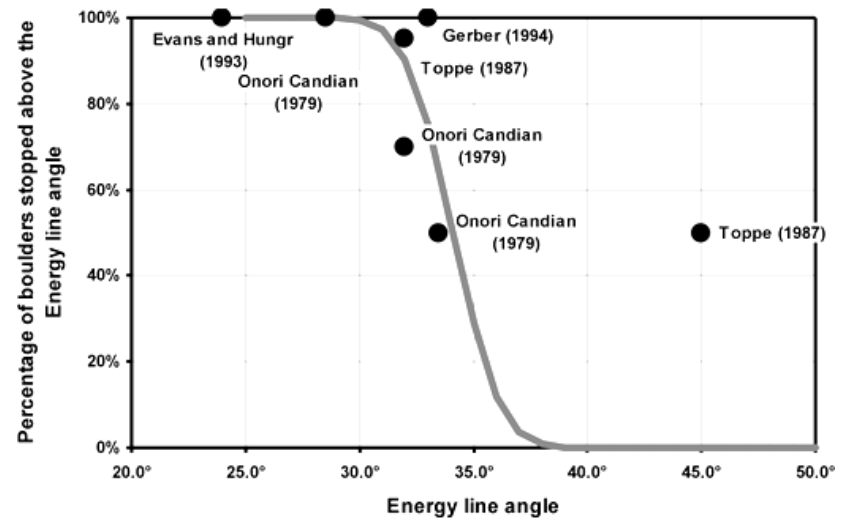

Fig. 2. Relationships between energy line angles and block distributions according to various authors. The gray curve is a fitting of all results (except the point Toppe, 1987 for $45^{\circ}$ ). The obtained value is $\phi_{\mathrm{p}}=34^{\circ}$ with a standard deviation of $1.62^{\circ}$.

As shown above, several authors (see Sect. 2) are giving limits for $\phi_{\mathrm{p}}$, linked to the percentage of block stopped before this point (Fig. 2). It is important to know if an extreme limit exists. Theoretically the answer is no, because assuming that on average a boulder behaves like a mass sliding along the topography, the distribution of the $\phi_{\mathrm{p}}$ of the block deposition or stopping points is a Gaussian function. Then, if the path is divided into small segments, each of them will have a random value for $\tan \phi_{\mathrm{p}}$, around a mean value. By using the central limit theorem (Jaboyedoff and Pedrazzini, 2010), it can be shown that these random values are distributed according to a Gaussian distribution. In practice, $\phi_{\mathrm{p}}$ values of $27^{\circ}$ to $37^{\circ}$ are usually used for rockfalls, but $\phi_{\mathrm{p}}$ can be much lower (10$15^{\circ}$ ) in case of rock avalanches.

If all the cells of potential rockfall source areas are used, the angle $\phi_{\mathrm{p}}$ must be set to a value close to the angle of repose of the talus slope: around $36-37^{\circ}$ for De la Noe and De Margerie (1888), 32-38 for Evans and Hungr (1993), and ranging from $26^{\circ}$ to $41^{\circ}$ for Jomelli and Francou (2000) (Fig. 1a). Theoretically, $35^{\circ}$ is the upper limit for a pile of spheres (Réka et al., 1997). This last value is also very close to one of the most common friction angles in rock mechanics. It can be assumed that the highly inclined talus slopes are caused by boulders with special shapes (like bricks that can form vertical walls). When moving down a talus with a slope angle of $35^{\circ}$, a boulder will keep roughly a constant velocity. Thus, at the bottom of the slope, the block will move beyond the limit defined by the $35^{\circ}$ cone slope to lose its energy completely. Then a slope angle lower than $35^{\circ}$ is necessary to stop the block. Thus, $33-35^{\circ}$ is a well-based $\phi_{\mathrm{p}}$ limiting range angle in order to predict the most common distant trajectories of blocks. Moreover, the starting point of the boulder must have a steeper slope than $35^{\circ}$; otherwise the block will not start to move.

For very large rockfall phenomena, the equation of Scheidegger (1973) may be used to estimate $\gamma$.

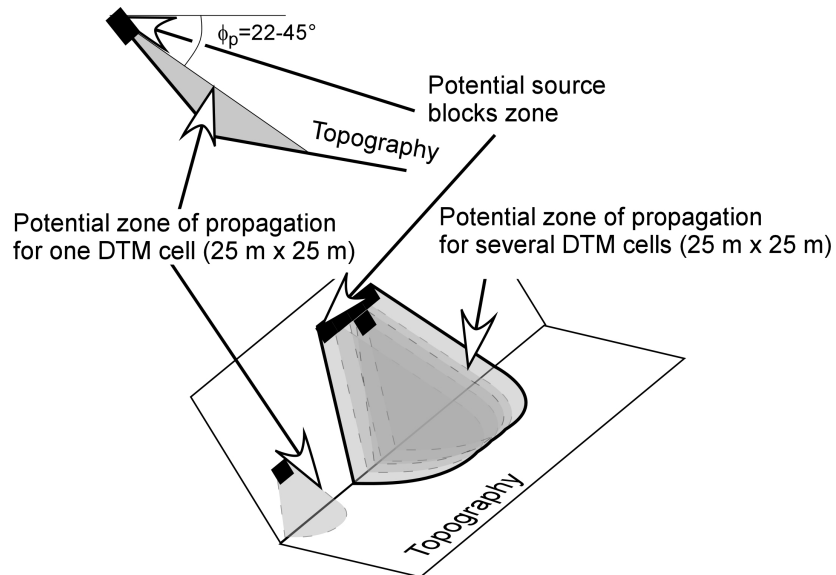

Fig. 3. Principle of the cone method, with cells as source areas. The resulting zone is the surface delineated by the higher cone surfaces or envelope of the whole pixels source of individual cones.

\section{Cone method implementation}

CONEFALL estimates the potential rockfall propagation area using a DTM and a grid file containing all the rockfall source areas as input data. It calculates the rockfall propagation area for each rockfall source cell. The routine of detecting whether a DTM cell is located below the energy line, i.e. in the propagation area, is equivalent to consider that a cell is located within a cone. This rather simple rule can be implemented by checking if:

$\Delta x^{2}+\Delta y^{2}-\operatorname{ctg}\left(\phi_{\mathrm{p}}\right)^{2} \cdot(H-h(x))^{2}<0$ and $h(x)<H(5)$

where $\Delta x$ and $\Delta y$ are the horizontal $x$ and $y$ distances of the DTM point to the source cell (the apex of the cone), $h(x)$ is the elevation of the cone apex, $H$ is the altitude of the rockfall source point, and $\left(\pi / 2-\phi_{\mathrm{p}}\right)$ is the angle of aperture of the cone (Figs. $1 \mathrm{~b}$ and 3 ). Note that some non-continuous areas can be obtained by this simple method. They can be avoided using the intersection of these results with a random walk algorithm (Gamma, 2000; Horton et al., 2008).

Various options for (a) the source and (b) the propagation areas are available in CONEFALL. (a) It is possible to use either all the cells contained in the source areas or only those belonging to the edges of these areas. Both methods define identical propagation areas, as the cones from the cells belonging to the upper border of a source area include all the cones from the lower cells of this source area. This option greatly reduced the computing time (10-100 times, depending on the source surface areas). Another similar option is to select automatically only the cells defining the lower edges of the source areas. This option is used for the "bottom of the cliff" method of Evans and Hungr (1993). In order to detect the cliff bottoms, the cells of the full source areas are divided into three different types: edge-cells, inside-cells, and nonsource cells. Using the DTM, the slope of each edge-cells is 
computed. If the slope dips towards a non-source cell, then the edge-cell is defined as a bottom cliff cell (Fig. 4a, b). If a source area is not a convex polygon or if it contains nonsource cells, the algorithm may generate artefacts. To correct inconsistencies produced by this automatic procedure, a tool to correct the source files manually has been implemented (Fig. 4c).

(b) In CONEFALL, the main parameter controlling the propagation is the cone angle which has a fixed value. Without further indication, the lateral propagation (dispersion) is defined by the intersection of the cone with topography. But the dispersion can also be limited using an azimuth and a tolerance angle from the source cell. Different types of outputs can be generated by CONEFALL. The main type is a grid containing the zones where rockfall boulders can propagate. In this grid, the value 1 indicates that the cell inside is at least one cone of propagation, and the value -1 indicates that the cell is outside any propagation area.

For each cell of the computed propagation area, it is also possible to count the number of contributing source cells by counting the number of cones including the propagation cell. This yields information on the zones that can be affected by the greatest number of blocks. The output file is then a grid of integer. Note that this counting is strongly dependent on the type of source area used, i.e. border, bottom or entire source area. The best option is to use a complete source area that is an entire cliff in order to get a count representative of the size of the contributing area.

In addition to this, using Eq. (3) CONEFALL can produce maps of maximum or mean velocities and energies, for each cell within the propagation area. A velocity correction factor, $f_{\mathrm{v}}$, may take a value other than 1 . Assuming $E_{\text {rot }} / E_{\text {tot }}$ is the ratio of rotational energy with total kinetic energy, and using Eq. (4), the translation velocity $v_{\mathrm{t}}$ can be expressed by:

$v_{\mathrm{t}}(x)=\sqrt{\left(1-\frac{E_{\mathrm{rot}}}{E_{\mathrm{tot}}}\right) 2 g \Delta h}=f_{\mathrm{v}} \sqrt{2 g \Delta h}$

Assuming that rotational energies represent around $20 \%$ of the total kinetic energy of a boulder (Gerber, 1994), $f_{\mathrm{v}}$ is then set to $0.9=\sqrt{0.8}$. This factor can be determined using field observations to obtain a more precise estimation of rock-fall translational velocities. Similar considerations hold for the estimation of rockfall energies, except that a mean block mass must be determined. Mean values of velocities or energies are usually computed using the full source areas. For the maximum values, it is possible to use only the edges of the source areas without changing the final results. Other configurations are left to the preferences of the user.

The CONEFALL software has been written in Microsoft Visual Basic ${ }^{\circledR}$ 6, first under Windows 98 and later on under Windows XP. The program can handle two types of input grid files, ArcGIS (*.ASC) files and Surfer 6.0 (*.GRD) ASCII files (Golden, 2002). DTM and rockfall source areas are provided as grid files and must have both the same geographical
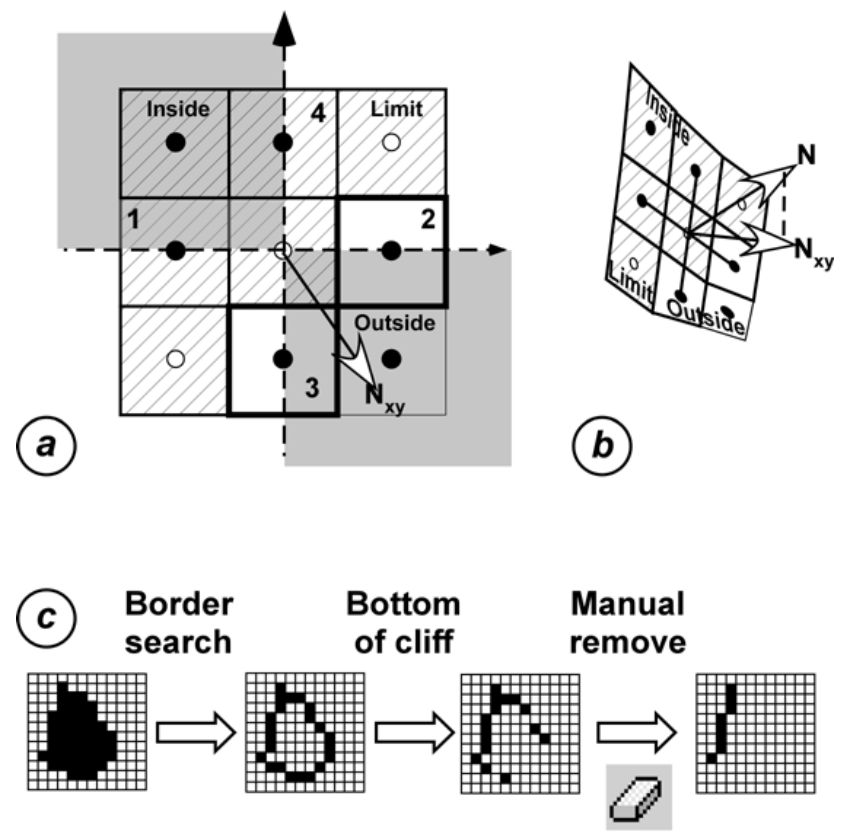

Fig. 4. (a) Illustration of the procedure of border identification. Any pixel that has a neighbouring point at the locations 1,2, 3 or 4 with at least one blank pixel (no cliff) is a border. To extract the bottom of the cliff, the space is divided into 3 types of pixels: inside cliff (light grey), border (dark grey) and white outside. (b) To identify a bottom pixel the normal vector $N$ to the pixel is estimated, and if it is located above its $\mathrm{x}-\mathrm{y}-\mathrm{0}$ component the pixel is designated as belonging to the bottom of the cliff. (c) Different possibilities for the modification of cliff areas.

coordinates and the same number of rows and columns. The rockfall source cells are coded by integers $\left(0-359^{\circ}\right)$ and other grid cells must be set to -1 . Depending on the type of analysis, the output file contains integer or floating point values. Cells outside the propagation areas have values of -1 . Each computer run or project can be saved and loaded (file menu) in a project text file (*.PRC) that contains all the necessary filenames and computation options.

\section{Applications}

The rock instability of "les Crétaux", located near Sion (Switzerland) is used as example. In August 1985, a rockfall occurred from an altitude of about $1400 \mathrm{~m}$ to the valley floor, at an altitude of about $450 \mathrm{~m}$ (Fig. 5). About fifty blocks reached the vineyards of the Rhône valley. The total rockfall volume was estimated at about $800000 \mathrm{~m}^{3}$, and single boulders ranged in size from $0.03 \mathrm{~m}^{3}$ to $80 \mathrm{~m}^{3}$ (Descoeudres, 1990; Rouiller, 1990, Labiouse and Descoeudres, 1999). In the area, different investigations on the rockfall trajectories were carried out using the 3-dimensional rockfall simulation code EBOUL (Descoeudres and Zimmermann, 1987; Dudt and Heidenreich, 2001). The upper part of the study area is a 


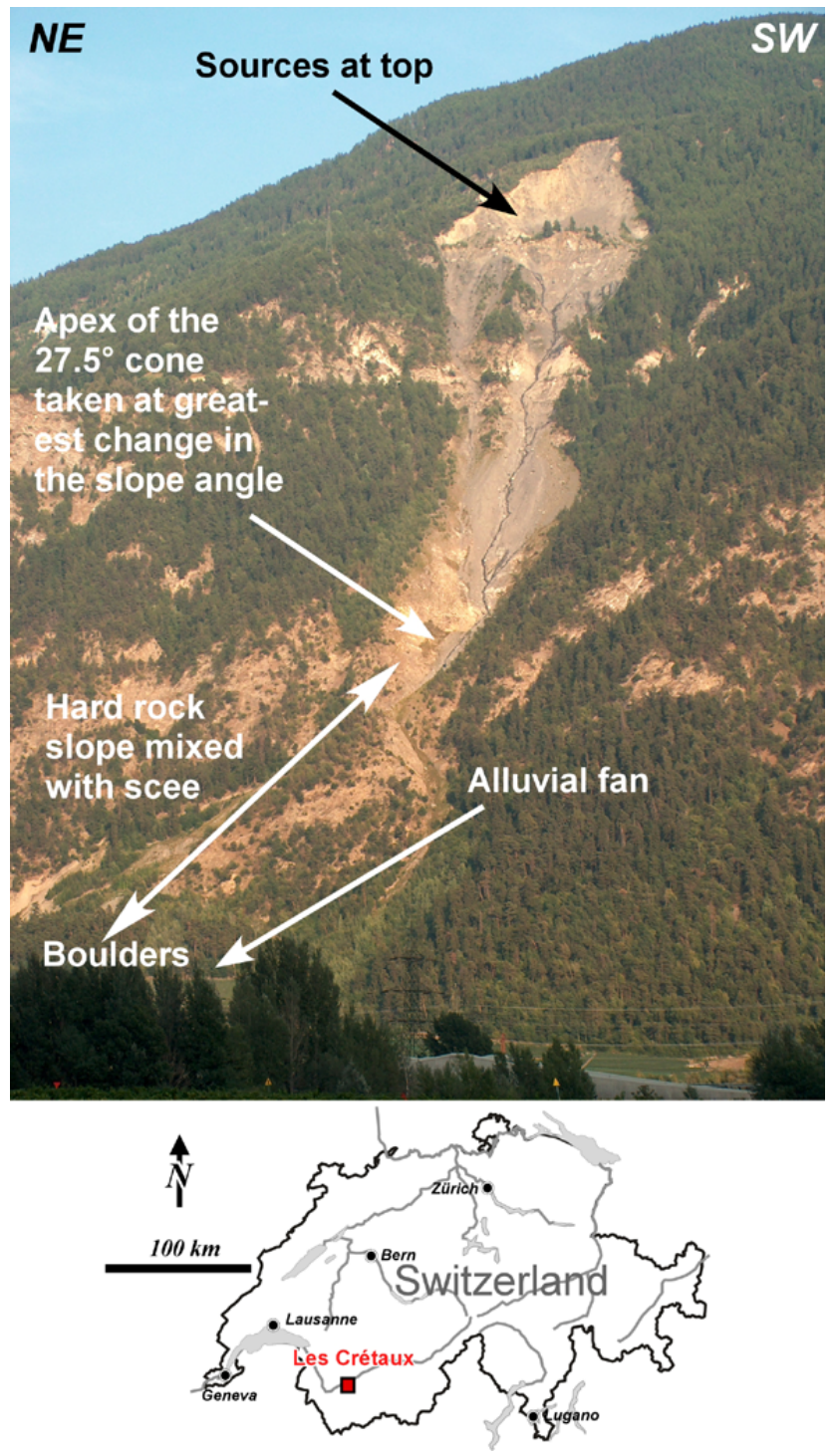

Fig. 5. Les Cretaux location and picture.

steep scree slope containing moved masses and small cliffs. The middle part is a hard rock slope mixed with scree which ends with an alluvial fan, mainly occupied by vineyards. The upper slope gradient is about $40^{\circ}$, making the use of the upper limit of the $\phi_{\mathrm{p}}$ angle $\left(35^{\circ}\right)$ a good approximation. Lower values of $\phi_{\mathrm{p}}$ would represent a more elastic terrain. This implies that the lower part slows down the blocks rapidly because of the large plasticity of the soil.

Using all the rockfall source cells, the velocity and energy are computed assuming a rock mass of $3200 \mathrm{~kg}$ (corresponding to a rock of more than $1 \mathrm{~m}^{3}$ ). The rockfall volume was selected so that our simulations could be compared to the simulation produced by Jaboyedoff et al. (2005). Figure 6 shows that rockfall blocks are all located within the $35^{\circ}$ cones. The more distant point is located at $37^{\circ}$ from the top of the cliff. This shows that the $35^{\circ}$ limiting angle is consis-

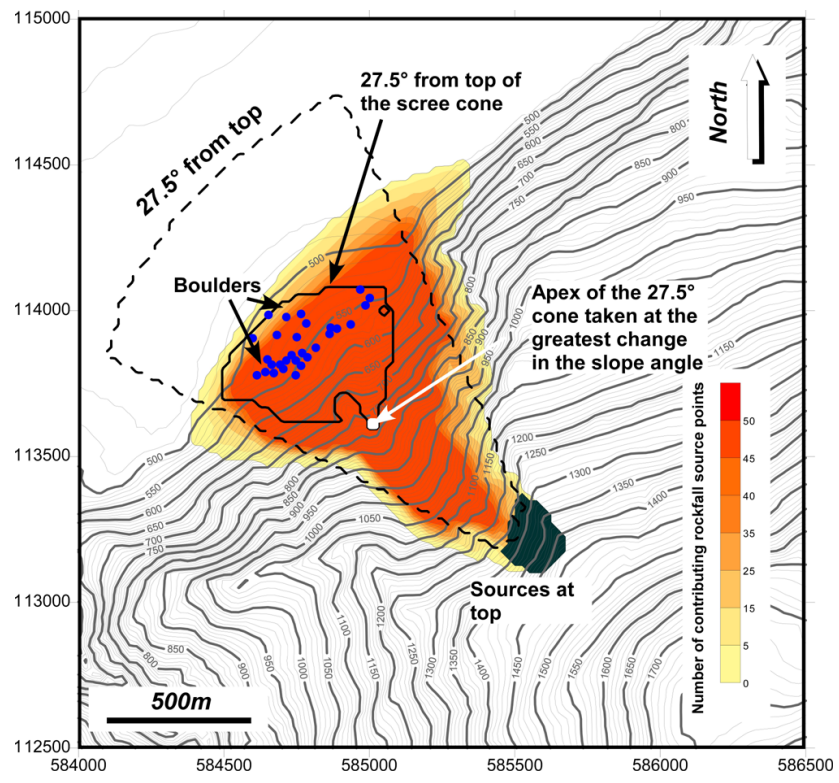

Fig. 6. The area in black is representing the source cells. The yellow to red scale is the count of the number of source points potentially contributing to the rockfall propagation zone. The black dashed line indicates the cone taken at the bottom of the source area in black with a $\phi_{\mathrm{p}}=27.5^{\circ}$ and limits equal to $315^{\circ} \pm 20^{\circ}$. The black line indicates the cone taken with an apex taken at the greatest change in the slope angle with a $\phi_{\mathrm{p}}=27.5^{\circ}$. (DTM reproduced with the permission of the Swiss Federal Service of the Topography, BA034918.)

tent with a scree-like topography. In the present case, all the results of the model are identical regardless of whether all the source cells are used or not. The lateral extension of the zone of propagation is larger than the observed spread of rockfall blocks (Fig. 6). However, in comparison to trajectory simulations (see Jaboyedoff et al., 2005), the difference of spread is small, but the simulations indicate a maximum run-out distance for a few boulders further than the $35^{\circ}$ slope cones. It must be noted that if the number of contributing source cells in the propagation area is used (Fig. 6), all the boulders are included in the area with more than 45 contributing cones for a total number of 50 source cells. The zone of 50 contributing cones included 30 boulders over a total of 31 . This gives a clear indication on the most rockfall-prone area.

The maximum total kinetic energy of a $3200 \mathrm{~kg}$ boulder is estimated to $4200 \mathrm{~kJ}$, which is slightly higher than the results of the simulations performed with EBOUL (see Jaboyedoff et al., 2005). The location of the maximum kinetic energy is not centred on the main channel of trajectories defined by the topography but on a side which is seldom reached by boulders (Fig. 7). This is one of the limitations of the cone method. In reality, rockfall boulders are slowed down in this region, because the impacts required to make the block turn in this direction are highly energy dissipative, due to the local topography and the superficial material. Following the same 

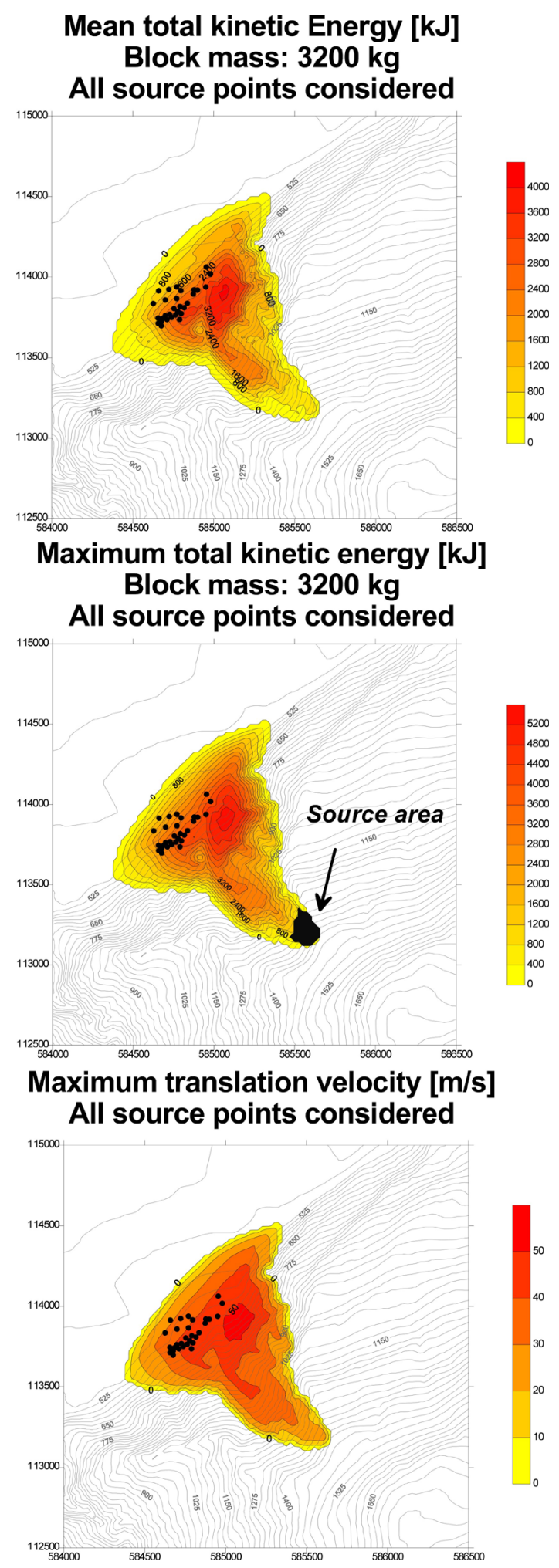

Fig. 7. Computations of energies and velocities for $3200 \mathrm{~kg}$ blocks using the Surfer program. (DTM reproduced with the permission of the Swiss Federal Service of the Topography, BA034918.) argument, the maximum total kinetic energy is estimated to $3500 \mathrm{~kJ}$, and the maximum mean translational velocity (using a velocity factor $=0.9)$ is around $42 \mathrm{~m} \mathrm{~s}^{-1}\left(150 \mathrm{~km} \mathrm{~h}^{-1}\right)$. This is in agreement with the observed maximum translation velocity obtained by Descoeudres (1990) from the analysis of a video record.

Using the "bottom of the cliff" method (Evans and Hungr, 1993) and selecting an angle of $27.5^{\circ}$, a wider area of propagation is then obtained and is compatible with the extreme boulders simulated with EBOUL (see Fig. 12 in Jaboyedoff et al., 2005) (Fig. 6). To better constrain the potential propagation area, the dispersion is limited by an azimuth and a lateral tolerance angle of $315^{\circ} \pm 20^{\circ}$. The result of the "bottom of the cliff" model appears to be greatly overestimated. This is because the morphology in our example is not a cliff-slope as in the Rocky Mountains, where Evans and Hungr (1993) developed their method. The $27.5^{\circ}$ area of propagation compared with 20000 trajectories simulated by EBOUL (Jaboyedoff et al., 2005) contains $99.8 \%$ of the simulated block stoppage points.

Nonetheless, the application of the cone model can also be refined. If we consider that a boulder loses most of its energy at the toe of a cliff or of a channel or at the greatest change in the slope angle corresponding to the apex of the cone composed by hard rock and scree slope, a $\phi_{\mathrm{p}}$ angle of $27.5^{\circ}$ can be used by analogy assuming that the apex of the cone is the location of strong energy loss. The computation of a cone centred at this apex shows that all the observed boulders are included in the obtained propagation zone (Fig. 6).

CONEFALL has also been applied at a regional scale to the County de Vaud (Switzerland), a $3200 \mathrm{~km}^{2}$ region. To identify the rockfall source areas, slope angle thresholds (from $47^{\circ}$ to $54^{\circ}$ ) were applied according to the local geology and a slope angle histogram analysis (Loye et al., 2009). The $\phi_{\mathrm{p}}$ angle was set to $33^{\circ}$ in order to be conservative. In addition, on the plain (significant zone with slope angle below $11^{\circ}$ ), the propagation area was limited to stripes of $100 \mathrm{~m}$ along the flank of the valley). The results of this regional study have been shown to be consistent with field observations (Jaboyedoff et al., 2008) (Fig. 8).

\section{Discussion and conclusions}

The cone method can be useful and efficient compared to other methods for several reasons. First, kinematics models need detailed knowledge of field characteristics. The distance of propagation of a rockfall is sensitive to the coefficients of restitution at impact points. As a consequence, a detailed field survey must be performed to get suitable impact parameters, and results must very often be adjusted to be in agreement with field evidence. For large and rapid surveys, it is not possible to collect all the required field data for kinematics-based modelling. In such cases the energy line cone method is more suitable. In 3-dimensions, the method 


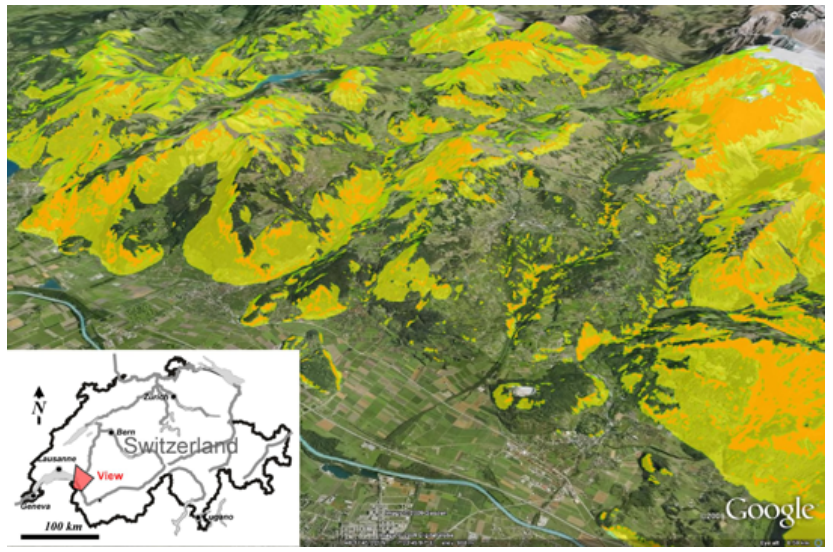

Fig. 8. View of rockfall indicative map of the Canton de Vaud based on the conefall method with $\phi_{\mathrm{p}}$ of $33^{\circ}$ using Googlearth (see Loye et al., 2009 for a detailed description of the map characteristics).

of the energy line angle leads to a cone that defines "lines of energy".

Nevertheless, the cone method must be applied carefully because the energy line angle varies greatly according to various authors (Fig. 1). In addition, in our experience the results obtained indicate that cones with a $\phi_{\mathrm{p}}$ angle from $33^{\circ}$ to $35^{\circ}$ provide good estimations of propagation zones and energies in alpine areas. For a high vertical cliff with a scree slope at its toe, the Evans and Hungr method (i.e., "bottom of the cliff or shadow angle approach") provides better estimates of the propagation zones. Further refinements of the cone method require the introduction of energy lines along the flow-paths. This can be performed with algorithms similar to those used for debris-flows using $D \infty$ flow path and flow dispersion (Holmgren, 1994; Horton et al., 2008; Blahut et al., 2010; Kappes et al., 2011), adding a threshold for the velocity (Horton et al., 2008) or a maximum energy loss from one to another pixel.

Going beyond the previous general statement, the example of les Crétaux shows that energy line angle methods can be applied in several ways with a finer tuning. First, the 50 boulders are included in the $35^{\circ}$ cone centered on the main instability. However, this is not always sufficient to include the extreme run-out blocks. In the simulations performed with EBOUL, $1.75 \%$ of the blocks are out of the $35^{\circ}$ energy line angle limit and $0.25 \%$ of them propagate further than the $27.5^{\circ}$ limit defined from the top of source area (see Jaboyedoff et al., 2005). This is consistent with observations considering that only 50 endpoints boulders locations are recorded and that the $27.5^{\circ}$ limit is very close to the extreme runout. In addition to using an adapted "bottom of cliff" $27.5^{\circ}$ method, placing the source at the main slope angle change at the location where the rebounds dissipate the maximum of energy, it is possible to obtain all the observed boulders inside the limit. This example shows that the CONEFALL method can not be applied blindly, the geomorphology and the goal of a study will directly influence the design of the chosen parameters, i.e. rockfall source areas, bottom of cliff or other morphological arguments. $\phi_{\mathrm{p}}$ must be then chosen either using previous study or deducing from local field observations.

The CONEFALL method is a good way to get first estimations of rockfall "propagation zones", velocities or energies. At a regional scale the software should be used only as a preliminary mapping tool to delineate rock prone areas using the simple, binary option outlining the areas that can be affected by falling boulders or by counting the number of contributing cones. Continuous variables, such as energy or velocity, should only be used when the morphology has first been inspected carefully to insure correct analysis (selecting among the different possibility of $\phi_{\mathrm{p}}$ angle or the location of the source cells). It must be noted that the shadow angle approach is strongly dependent on the slope morphology. If detailed information are available at regional scale, it is possible to use more sophisticated 3-D models based on trajectory modelling (Guzzetti et al., 2003; Crosta and Agliardi, 2004; Frattini et al., 2008; Dorren et al., 2006). For rock avalanches, CONEFALL may be employed using lateral extension, and $\phi_{\mathrm{p}}$ angles calculated by the relationship between $\phi_{\mathrm{p}}$ angle and the volume after Scheidegger (1973).

Finally, CONEFALL appears to be a suitable standalone solution to perform fast studies of rockfall propagation at regional scale, and such a model can be easily implemented in a GIS environment with programming capabilities.

\section{Supplementary material related to this article is available online at: http://www.nat-hazards-earth-syst-sci.net/11/819/2011/ nhess-11-819-2011-supplement.zip.}

Acknowledgements. We thank the Swiss Canton de Vaud regional Authorities and the Cantonal Fire Insurance for financial support within the project CADANAV and for authorizing publication of the results. The first author thanks the Société Academique Vaudoise for financial support. An earlier version of the manuscript benefited from the comments of F. Guzzetti from the IRPI Perugia (Italy) and M.-H. Derron from University of Lausanne. One anonymous reviewer, and Luuk Dorren from the Federal Office of Environment of Switzerland and Andreas Günther from the Federal Institute for Geosciences and Natural Resources of Germany have greatly improved the manuscript. A. Loye provided one figure for this article. We thank all others for their constructive advice.

Edited by: A. Günther

Reviewed by: L. K. A. Dorren and another anonymous referee 


\section{References}

Agliardi, F. and Crosta, G.: High resolution three-dimensional numerical modelling of rockfalls, Int. J. Rock Mech. Min., 40, 455471, doi:10.1016/S1365-1609(03)00021-2, 2003.

Aksoy, H. and Ercanoglu, M.: Determination of the rockfall source in an urban settlement area by using a rule-based fuzzy evaluation, Nat. Hazards Earth Syst. Sci., 6, 941-954, doi:10.5194/nhess-6-941-2006, 2006.

Azimi, C., Desvarreux, P., Giraud, A., and Martin-Coher, J.: Méthode de calcul de la dynamique des chutes de blocs. Application à l'étude du versant de la montagne de La Pale (Vercors), Bulletin de liaison des Laboratoires des Ponts et Chaussées, 122, 93-102(A), 1982 (in French).

Blahut, J., Horton, P., Sterlacchini, S., and Jaboyedoff, M.: Debris flow hazard modelling on medium scale: Valtellina di Tirano, Italy, Nat. Hazards Earth Syst. Sci., 10, 2379-2390, doi:10.5194/nhess-10-2379-2010, 2010.

Crosta, G. B. and Agliardi, F.: Parametric evaluation of 3D dispersion of rockfall trajectories, Nat. Hazards Earth Syst. Sci., 4, 583-598, doi:10.5194/nhess-4-583-2004, 2004.

Crosta, G., Frattini, P., and Sterlacchini, S.: Valutazione e gestione del rischio da frana,. RegioneLombardia, Milano, 169 pp., 2001.

Corominas, J.: The angle of reach as a mobility index for small and large landslides, Can. Geotech. J., 33, 260-271, doi:10.1023/B:NHAZ.0000007094.74878.d3, 1996.

De la Noe, G. and De Margerie, E.: Du façonnement des versants, in: Les formes du terrain, Imprimerie Nationale, Chapter 3, 3947, 1888 (in French).

Descoeudres, F.: L'éboulement des Crêtaux. Aspects géotechniques et calcul dynamique des chutes de blocs, Publication Société Suisse de Mécanique des Sols et des Roches, 121, 19-25, 1990 (in French).

Desceoudres, F. and Zimmermann, T.: Three-dimensional dynamic calculation of rockfalls, in: Proceedings 6th International Congress of Rock Mechanics, Montreal, Canada, 337342, 1987.

Dorren, L. K. A. and Seijmonsbergen, A. C.: Comparison of three GIS-based models for predicting rockfall runout zones at a regional scale, Geomorphology, 56(1-2), 49-64, doi:10.1016/S0169-555X(03)00045-X, 2003.

Dorren, L. K. A., Berger, F., and Putters, U. S.: Real-size experiments and 3-D simulation of rockfall on forested and nonforested slopes, Nat. Hazards Earth Syst. Sci., 6, 145-153, doi:10.5194/nhess-6-145-2006, 2006.

Dudt, J. P. and Heidenreich, B.: Treatment of uncertainty in a threedimensional numerical simulation model for rockfalls, in: International Conference on Landslides - causes, impacts and countermeasures, edited by: Kühne, M., Einstein, H. H., Krauter, E., Klapperich, H., and Pötter, R., 17-21 June 2001, Davos, Switzerland, VGE, Essen, 507-514, 2001.

Evans, S. and Hungr, O.: The assessment of rockfall hazard at the base of talus slopes, Can. Geotech. J., 30, 620-636, doi:10.1139/t93-054, 1993.

Frattini, P., Crosta, G., Carrara, A., and Agliardia, F.: Assessment of rockfall susceptibility by integrating statistical and physically-based approaches, Geomorphology, 94, 419-437, doi:10.1016/j.geomorph.2006.10.037, 2008.
Gamma, P.: dfwalk-Ein Murgang-Simulationsprogramm zur Gefahrenzonierung, Geographisches Institut der Universität Bern, Switzerland, 2000 (in German).

Gerber, W.: Beurteilung des Prozesses Steinschlag, Forstliche Arbeitsgruppe Naturgefahren (FAN), Herbstkurs Poschiavo, Kursunterlagen, WSL, Birmensdorf, 20 pp., 1994 (in German).

Ghazipour, N., Uromeihy, A., Entezam, I., Ansari, F., and Pirouz, M.: The use of Cone-Fall theory for evaluation of rock-fall hazard along the Chaloos-Road (Pol-e-Zanguleh - Marzan-Abad), Geosciences, 17, 160-169, 2008.

Golden: Srurfer version 8.01, Golden software Inc., 2002.

Guzzetti, F., Crosta, G., Detti, R., and Agliardi, F.: STONE : a computer program for the three-dimensional simulation of rockfalls, Computat. Geosci., 28, 1079-1093, doi:10.1016/S00983004(02)00025-0, 2002.

Guzzetti, F., Reichenbach, P., and Wieczorek, G. F.: Rockfall hazard and risk assessment in the Yosemite Valley, California, USA, Nat. Hazards Earth Syst. Sci., 3, 491-503, doi:10.5194/nhess-3491-2003, 2003.

Heim, A.: Bergsturz und Menschenleben, Fretz und Wasmuth, Zurich, 218 pp., 1932 (in German).

Heinimann, H. R., Hollenstein, K., Kienholz, H., Krummenacher, B., and Mani, P.: Methoden zur Analyse und Bewertung Von Naturgefahren, Umwelt - Materialen, 85 BUWAL, Switzerland, 247 pp., 1998 (in German).

Hoek, E.: Practical Rock engineering, Rocsciences, available at: http://www.rocscience.com/education/hoeks_corner, 313 pp., 2007.

Holmgren, P.: Multiple flow direction algorithms for runoff modelling in grid based elevation models: An empirical evaluation, Hydrol. Process., 8, 327-334, doi:10.1002/hyp.3360080405, 1994.

Horton, P., Jaboyedoff, M., and Bardou, E.: Debris flow susceptibility mapping at a regional scale, 4th Canadian Conference on Geohazards, Québec, Canada, May 20-24, 2008.

Hungr, O. and Evans, S. G.: Engineering evaluation of fragmental rockfall hazards, Proceedings 5th International Symposium on Landslides, Lausanne, Switzerland, 1, 685-690, 1988.

Jaboyedoff, M. and Labiouse, V.: Preliminary assessment of rockfall hazard based on GIS data, in: 10th International Congress on Rock Mechanics ISRM 2003 - Technology roadmap for rock mechanics, South African Institute of Mining and Metallurgy, Johannesburg, South Africa, 575-578, 2003.

Jaboyedoff, M. and Pedrazzini, A.: The usefulness of the reach angle concept for hazard zoning using statistical approach. Geophysical Research Abstracts, Vol. 12, EGU2010-5409, 2010.

Jaboyedoff, M., Dudt, J. P., and Labiouse, V.: An attempt to refine rockfall hazard zoning based on the kinetic energy, frequency and fragmentation degree, Nat. Hazards Earth Syst. Sci., 5, 621-632, doi:10.5194/nhess-5-621-2005, 2005.

Jaboyedoff, M., Giorgis, D., and Riedo, M.: Apports des modèles numériques d'altitude pour la géologie et l'étude des mouvements de versant, Bull. Soc. Vaud. Sc. Nat., 90, 1-21, 2006 (in French).

Jaboyedoff, M., Pedrazzini, A., Horton, P., Loye, A., and Surace, I.: Preliminary slope mass movements susceptibility mapping using LIDAR DEM, Proceedings of 61st Canadian Geotechnical Conference, 419-426, 2008. 
Jomelli, V. and Francou, B.: Comparing the characteristics of rockfall talus and snow avalanche landforms in an Alpine environment using a new methodological approach: Massif des Ecrins, French Alps, Geomorphology, 35, 181-192, doi:10.1016/S0169555X(00)00035-0, 2000.

Kappes, M. S., Malet, J.-P., Remaître, A., Horton, P., Jaboyedoff, M., and Bell, R.: Assessment of debris-flow susceptibility at medium-scale in the Barcelonnette Basin, France, Nat. Hazards Earth Syst. Sci., 11, 627-641, doi:10.5194/nhess-11-627-2011, 2011.

Labiouse, V. and Desceoudres, F.: Possibilities and difficulties in predicting rockfall trajectories, in: Joint Japan-Swiss seminar on impact load by rockfalls and design of protection structures, Kanazawa, edited by: Masuya, H. and Labiouse, V., 29-36, 1999.

Labiouse, V., Heidenreich, B., Devareux, P., Viktorovitch, M., and Guillemin, P.: Etudes trajectographiques, in: Programme Interreg IIc - "Falaises", Prévention des mouvements de versants et des instabilités de falaises, Confrontation des méthodes d'études des éboulements rocheux dans l'arc alpin, edited by: Carere, K., Ratto, S., and Zanolini, F., 155-211, 2001 (in French).

Lan, H., Martin, C. D., and Lim, C. H.: RockFall analyst: a GIS extension for three-dimensional and spatially distributed rockfall hazard modelling, Computat. Geosci., 33, 262-279, 2007.

Lied, K.: Rockfall problems in Norway, in: Rockfall dynamics and protective work effectiveness, ISMES, Bergamo, 90, 51-53, 1977.

Loye, A., Jaboyedoff, M., and Pedrazzini, A.: Identification of potential rockfall source areas at a regional scale using a DEMbased geomorphometric analysis, Nat. Hazards Earth Syst. Sci., 9, 1643-1653, doi:10.5194/nhess-9-1643-2009, 2009.

Menéndez Duarte, R. and Marquinez, J.: The influence of environmental and lithologic factors on rockfall at a regional scale: an evaluation using GIS, Geomorphology, 43, 117-136, doi:10.1016/S0169-555X(01)00126-X, 2002.

Onofri, R. and Candian, C.: Indagine sui limiti di massima invasione di blocchi rocciosi franati durante il sisma del Friuli del 1976, Reg. Aut. Friuli - Venezia Giulia, Cluet, 42 pp., 1979 (in Italian).
Piteau, D. R. and Clayton, R.: Computer Rockfall Model, Proceedings Meeting on Rockfall Dynamics and Protective Works Effectiveness, Bergamo, Italy, ISMES, 90, Bergamo, Italy, 123-125, 1978.

Réka, A., Istan, A., Hornbaker, D., Schiffer, P., and Barabasi, A. L.: Maximum angle of stability in wet and dry spherical granular media, Phys. Rev. E, 56, R6271-R6274, doi:10.1103/PhysRevE.56.R6271, 1997.

Ritchie, A. M.: Evaluation of rock-fall and its control, Highway research record, 17, 13-28, 1963.

Rouiller, J. D.: L'éboulement des crétaux - Isérables - Riddes (Valais), Soc. Suisse de Mécanique des Sols et des Roches, 121, 15-17, 1990 (in French).

Ruelle, D.: Déterminisme et prédictibilité, in: L'ordre et le chaos, Bibliothèque pour la science, Belin, 136-145, 1987 (in French).

Scheidegger, A. E.: On the prediction of the reach and velocity of catastrophic landslides, Rock Mech., 5, 231-236, 1973.

Scioldo, G.: Guide à l'usage de ISOMAP - INQUIMAP - ROTOMAP, Geo \& Soft, 66 pp., 2001 (in French).

Spang, R. M.: Protection against rockfall - Stepchild in the design of rock slopes, 6th International Congress on Rock Mechanics, International Society for Rock Mechanics, 551-557, 1987.

Stevens, W.: Rockfall 4.0 Software for the Analysis of Falling Rocks on a Steep Slope, B.A.Sc. thesis, Department of Civil Engineering, University of Toronto, Ontario, Canada, 1996.

Toppe, R.: Terrain models: a tool for natural hazard mapping, in: Avalanche formation, movement and effects, edited by: Salm, B. and Gubler, H., International, Association of Hydrological Sciences, Wallingford, UK, 162, 629-638, 1987.

Utelli, H. H.: Die Möglichkeiten von GIS bei der Beurteilung der Steinchlaggefahr im alpinen, Bereich Bull. Angew. Geol., 3-17, 1999 (in German).

Van Dijke, J. J. and Van Westen, C. J.: Rockfall hazard: a geomorphologic application of neighbourhood analysis with Ilwi, ITC Journal, 1990-1, 40-44, 1990.

Wieczorek, G. F., Morrissey, M. M., Iovine, G., and Godt, J.: Rockfall Potential in the Yosemite Valley, California., USGS Open-file Report, 99-578, 1999. 